\title{
Brain's Hemisphere Lateralization and Learning Styles in Engineering Education
}

\author{
A. Gomathi ${ }^{1 *}$, Dr. K.V. Krishna ${ }^{2}$
}

\section{ABSTRACT}

The study explored various functions of the brain or hemisphere lateralization and it relevance to learning style and education namely how it relates to other style constructs (visual, Aural, verbal, physical, logical, social and solitary), gender and department stream how these are likely to impact upon learning in educational setting. Generally learning style can be described as a set of factors, behaviors, and attitudes that facilitate learning for an individual in a given situation. Students learn differently from each other and it has been determined that brain structure influences language structure acquisition. It has also been shown that different hemispheres of the brain contain different perception. The implications of these finding for the assessment of brain lateralization and their learning style preferences are discussed.

Keywords: Brain Dominance, Gender With Learning Style, Department Stream, Hemisphere Lateralization

The neuroscience is study of understand the relationships between the structures of the nervous system and a person's behavior. It is difficult or unethical to directly study the nervous system during a behavior and indirect methods must be used instead. One example of such an indirect method is using a subject's preferred hand to predict which of the two Cerebral Hemispheres is dominant. The are some difficulties with his method of studying lateralization of function but if it can be better understood it could have many practical and theoretical implications for the study of neuroscience. The Cerebral Hemispheres are very similar in appearance, but they differ significantly in their structure. One of the best known differences between the two structures is motor control; the right hemisphere controls the left half of the body and the left hemisphere controls the right half of the body. These motor control differences were discovered mainly through the examination of paralysis caused by stokes or other damage to a specific hemisphere.

\footnotetext{
${ }^{1}$ Ph.D Part Time Research Scholar, Department of Psychology, Bharathiar University, Coimbatore. \& Assistant Professor, Department of Psychology, Sree Saraswathi Thyagaraja College (Autonomous), Pollachi. Coimbatore District, Tamilnadu, India

${ }^{2}$ Research Supervisor, \& Assistant Professor, Department of Psychology, Bharathiar University, Coimbatore, India *Responding Author Received: March 9, 2017; Revision Received: March 27, 2017; Accepted: March 30, 2017

(C) 2017 Gomathi A, Krishna K; licensee IJIP. This is an Open Access Research distributed under the terms of the Creative Commons Attribution License (www.creativecommons.org/licenses/by/2.0), which permits unrestricted use, distribution, and reproduction in any Medium, provided the original work is properly cited.
} 


\section{Brain's Hemisphere Lateralization and Learning Styles in Engineering Education}

\section{Objective of the study}

To find the relationship between brain's hemisphere lateralization and learning styles preferences

To examine the patterns emerge in their strategy use with regard to learning styles.

\section{LITERATURE REVIEW}

Herrmann, (2003). Hemispheres are in interaction with each other under normal circumstances. However, each has different basic functions. Herrmann states that separating the human brain into two parts as left / right brain is insufficient in terms of identifying the differences. In Herrmann's four quadrant brain model, which was formed in 1995, the upper left quadrant of the brain is shown with letter A, while others are shown in B, C and D counter clockwise. In the metaphorical Whole Brain Model of Herrmann, these four quadrants are right and left cerebral halves (upper right and left quadrants) and right and left limbic halves (lower right and left quadrants).

Honey \& Mumford, (2000) Educationalists introduced the concept of learning style as a "description of the attitudes and behaviours that determine our preferred way of learning". Therefore, it is important for the teacher to be aware of different ways to communicate the same content.

Kemal Özgena, Berna Tataroglua, Hüseyin Alkana (2011). It is assumed that learning involves a lot of complex components such as environmental, emotional, sociological, physiological, psychological ones (Dunn, s1983). During different stages of learning process, differences are observed between individuals and these are referred as individual differences in education. The brain dominance and learning style preferences of individuals are also regarded among individual differences. Knowing how learning takes place; and mental activities that are performed to reflect this on learning environment during learning process are important for brain hemisphere preferences and learning styles. For this reason, studies about brain hemispheres and learning styles continue to draw interest both in past and today.

McCarthy, Germain \& Lippitt, (2006). According to studies, left hemisphere exhibits a more analytic approach, while right hemisphere displays holistic and spatial approach. Each hemisphere has special mental abilities. The left hemisphere is analytical, abstract, verbal, digital, logical, sequential, and rational, while the right hemisphere is holistic, concrete, nonverbal, visual spatial, intuitive, simultaneous and analogical

Riad S. Aisami (2015) said the effectiveness of instruction is usually measured by the instruction's capability in enabling the target learners achieve the instruction's intended learning outcomes. Thus, in order for teachers and instructors to plan the instruction that meets their students' need, they ought to know how the students learn better based on their learning styles. The type of learning style mainly depends on the side of the brain, left and right, that a student uses the most. Therefore, teachers and instructors need also to know how the human brain functions in order to assess the learning styles of their students properly and so develop matching instructional strategies. 


\section{Brain's Hemisphere Lateralization and Learning Styles in Engineering Education}

Solso, Maclin \& Maclin, (2007: 80). The studies about split brain show that different types of information are processed in left and right brain hemispheres and the functions of these two hemispheres are different. While some people learn by hearing or reading words, others prefer seeing pictures, and or learn by doing (hands-on). Also, there are some people who learn better by analyzing or socializing, or some people like to learn individually, while others like to learn in groups. These different preferences of learning are referred to as the learning styles. Figure 1 presents learning styles overview that includes seven-learning styles: (1) visual (special), (2) verbal (linguistic), (3) aural (auditory), (4) logical (mathematical), (5) physical (kinesthetic), (6) Social (interpersonal), and Solitary (intrapersonal). This overview is based on (Learning-stylesonline.com, 2014).

Also, students can have a combination of two styles such as visual-verbal, visual-nonverbal, auditory-verbal, or physical-kinesthetic, or can have a mix of multiple learning styles. Evidently, students with multiple learning styles can benefit from multiple instructional strategies. However, the research does not provide evidence of the superiority of a particular combination or mix of multiple learning styles over another.

\section{METHOD}

Participants were 500 undergraduate engineering college students, included 338 male (67.6\%) and females 162 (32.4\%) who completed the Hermann Brain Dominance Inventory (HBDI) and Memletics Accelerated learning styles Inventory.

\section{Research and data collection}

The finalized questionnaire was administrated on sample of engineering college students.

\section{Data Analysis}

The data collected through questionnaire was coded and analyzed through SPSS 16.0, percentage score; chi-square value and one-way ANOVA were computed.

\section{RESULT}

Data collected through questionnaire was analyzed in light of objectives of the study. Gender wise, learning style wise calculated in percentages. To infer the significance of results, F-test and chi-square were applied. The findings drawn from the data analysis are given below.

Table 1 - Gender and Brain Dominance

\begin{tabular}{|l|l|l|l|l|}
\hline \multirow{2}{*}{ Gender } & \multicolumn{2}{|l|}{ Dominance } & \multirow{2}{*}{ Total } \\
\cline { 2 - 5 } & Bilaterlization & Left & Right & \\
\hline \multirow{2}{*}{ Male } & 47 & 140 & 151 & 338 \\
\cline { 2 - 5 } & $9.4 \%$ & $28.0 \%$ & $30.2 \%$ & $67.6 \%$ \\
\hline Female & 31 & 87 & 44 & 162 \\
\cline { 2 - 5 } & $6.2 \%$ & $17.4 \%$ & $8.8 \%$ & $32.4 \%$ \\
\hline \multirow{2}{*}{$\begin{array}{l}\text { Total } \\
\text { \% }\end{array}$} & $\mathbf{7 8}$ & $\mathbf{2 2 7}$ & $\mathbf{1 9 5}$ & $\mathbf{5 0 0}$ \\
\cline { 2 - 5 } & $\mathbf{1 5 . 6 \%}$ & $\mathbf{4 5 . 4 \%}$ & $\mathbf{3 9 . 0 \%}$ & $\mathbf{1 0 0 . 0 \%}$ \\
\hline
\end{tabular}

(C) The International Journal of Indian Psychology, ISSN 2348-5396 (e)| ISSN: 2349-3429 (p) | 25 
Brain's Hemisphere Lateralization and Learning Styles in Engineering Education

\begin{tabular}{|l|l|l|l|}
\hline Chi-Square Tests & Value & df & Asymp. Sig. (2-sided) \\
\hline Pearson Chi-Square & $\mathbf{1 4 . 1 7 3}^{\mathbf{a}}$ & $\mathbf{2}$ & $\mathbf{. 0 0 1}$ \\
\hline Likelihood Ratio & 14.580 & 2 & .001 \\
\hline N of Valid Cases & 500 & & \\
\hline a. 0 cells (.0\%) have expected count less than 5. The minimum expected count is 25.27. \\
\hline
\end{tabular}

There is no association between gender and brain dominance. The value of chi-square test (14.173) at low p-value of 0.001) indicate that the null hypothesis is rejected at 1 per cent level of significance. Hence it may be conclude that there is a significant difference between gender and brain dominance $(\mathrm{p}<0.01)$.

It focuses that 338 respondents are male category, 151 respondents (30.2\%) are using their right brain dominance and 31 respondents (9.4\%) are bilaterlization.

As regards 162 respondents are female category, 87 respondents (17.4\%) are using their left brain dominance and 31 respondents (6.2\%) are using their bilaterlization. The majority 338 respondents are male category (67.6\%) are using their right brain dominance.

Table 2 - Gender and Department level

\begin{tabular}{|l|l|l|l|}
\hline \multirow{2}{*}{ Gender } & Department & Total \\
\cline { 2 - 4 } & EEE & Mech. & \\
\hline Male & 180 & 158 & 338 \\
\cline { 2 - 4 } & $36.0 \%$ & $31.6 \%$ & $67.6 \%$ \\
\hline Female & 162 & 0 & 162 \\
\hline & $32.4 \%$ & $.0 \%$ & $32.4 \%$ \\
\hline Total & $\mathbf{3 4 2}$ & $\mathbf{1 5 8}$ & $\mathbf{5 0 0}$ \\
\hline $\mathbf{\%}$ & $\mathbf{6 8 . 4 \%}$ & $\mathbf{3 1 . 6 \%}$ & $\mathbf{1 0 0 . 0 \%}$ \\
\hline
\end{tabular}

\begin{tabular}{|l|l|l|l|}
\hline Chi-Square Tests & Value & df & Asymp. Sig. (2-sided) \\
\hline Pearson Chi-Square & $1.107 \mathrm{E} 2^{\text {a }}$ & 1 & .000 \\
\hline Likelihood Ratio & 156.683 & 1 & .000 \\
\hline N of Valid Cases & 500 & & \\
\hline a. 0 cells $(.0 \%)$ have expected count less than 5. The minimum expected count is 25.27. \\
\hline
\end{tabular}




\section{Brain's Hemisphere Lateralization and Learning Styles in Engineering Education}

There is no association between gender and department level. The value of chi-square test (1.107) at low p-value of 0.000) indicate that the null hypothesis is rejected at 1 per cent level of significance. Hence it may be conclude that there is a significant difference between gender and brain department $(\mathrm{p}<0.01)$.

It is clear that 342 respondents (68.4\%) were EEE students and low levels of 158 respondents (31.6\%) are Mechanical Engineering students. The majority of students are (68.4\%) EEE students.

Table 3- Department and Brain Dominance

\begin{tabular}{|l|l|l|l|l|}
\hline \multirow{2}{*}{ Department } & \multicolumn{2}{|l|}{ Dominance } & Total \\
\cline { 2 - 5 } & Bilaterlization & Left & Right & \\
\hline \multirow{2}{*}{ EEE } & 58 & 155 & 129 & 342 \\
\hline & $11.6 \%$ & $31.0 \%$ & $25.8 \%$ & $68.4 \%$ \\
\hline Total & 20 & 72 & 66 & 158 \\
\hline \% & $4.0 \%$ & $14.4 \%$ & $13.2 \%$ & $31.6 \%$ \\
\hline & $\mathbf{7 8}$ & $\mathbf{2 2 7}$ & $\mathbf{1 9 5}$ & $\mathbf{5 0 0}$ \\
\hline
\end{tabular}

\begin{tabular}{|l|l|l|l|}
\hline Chi-Square Tests & Value & df & Asymp. Sig. (2-sided) \\
\hline & $\mathbf{1 . 7 3 8}^{\text {a }}$ & $\mathbf{2}$ & .419 \\
\hline Pearson Chi-Square & 1.782 & 2 & .410 \\
\hline Likelihood Ratio & 500 & & \\
\hline N of Valid Cases & a. 0 cells (.0\%) have expected count less than 5. The minimum expected count is 24.65. \\
\hline
\end{tabular}

There is no association between department and brain dominance. The value of chi-square test (1.738) at high p-value of (0.419) indicates that the null hypothesis is accepted at 5 per cent level of significance. Hence it may be conclude that there is no significant difference between department and brain dominance ( $>00.01)$.

It is shows that out of 500 respondents, 78respondents were bilaterlization (15.6\%), 227 respondents (45.4\%) were left brain dominance and 195 respondents (39\%) were right brain dominance. The majority of EEE department students were using left brain dominance at 31 per cent. 
Brain's Hemisphere Lateralization and Learning Styles in Engineering Education

Table 4 One - way ANOVA Gender with Learning Style

\begin{tabular}{|c|c|c|c|c|c|c|}
\hline $\begin{array}{l}\text { Learning } \\
\text { style }\end{array}$ & Variable & \begin{tabular}{|l} 
Sum \\
Squares
\end{tabular} & of df & Mean Square & $\mathbf{F}$ & Sig. \\
\hline \multirow{3}{*}{ Visual } & Between Groups & .417 & 1 & .417 & \multirow{3}{*}{.930} & \multirow{3}{*}{.36} \\
\hline & Within Groups & 3.583 & 8 & .448 & & \\
\hline & Total & 4.000 & 9 & & & \\
\hline \multirow{3}{*}{ Aural } & Between Groups & .067 & 1 & .067 & \multirow{3}{*}{.229} & \multirow{3}{*}{.645} \\
\hline & Within Groups & 2.333 & 8 & .292 & & \\
\hline & Total & 2.400 & 9 & & & \\
\hline \multirow{3}{*}{ Verbal } & Between Groups & .100 & 1 & .100 & \multirow{3}{*}{.100} & \multirow{3}{*}{.760} \\
\hline & Within Groups & 8.000 & 8 & 1.000 & & \\
\hline & Total & 8.100 & 9 & & & \\
\hline \multirow{3}{*}{ Physical } & Between Groups & .817 & 1 & .817 & \multirow{3}{*}{1.823} & \multirow{3}{*}{$.21<$} \\
\hline & Within Groups & 3.583 & 8 & .448 & & \\
\hline & Total & 4.400 & 9 & & & \\
\hline \multirow{3}{*}{ Logical } & Between Groups & .100 & 1 & .100 & \multirow{3}{*}{.125} & \multirow{3}{*}{.733} \\
\hline & Within Groups & 6.400 & 8 & .800 & & \\
\hline & Total & 6.500 & 9 & & & \\
\hline \multirow{3}{*}{ Social } & Between Groups & .817 & 1 & .817 & \multirow{3}{*}{1.074} & \multirow{3}{*}{.330} \\
\hline & Within Groups & 6.083 & 8 & .760 & & \\
\hline & Total & 6.900 & 9 & & & \\
\hline \multirow[t]{3}{*}{ Solitary } & Between Groups & 1.219 & 1 & 1.219 & \multirow{3}{*}{2.226} & \multirow{3}{*}{.174} \\
\hline & Within Groups & 4.381 & 8 & .548 & & \\
\hline & Total & 5.600 & 9 & & & \\
\hline
\end{tabular}

There is no significant difference between gender and learning style. The above visual learning style reveals that the p-value is more than 0.05 ; the null hypotheses accept at 5 per cent level of significance. It is concluded that there is no significant difference between gender and visual learning style $(\mathrm{F}=.930 ; \mathrm{p}>0.05)$.

The above table aural learning style reveals that the p-value is more than 0.05; the null hypotheses accept at 5 per cent level of significance. It is concluded that there is no significant difference between gender and aural learning style $(\mathrm{F}=.229$; $\mathrm{p}>0.05)$.

The above table verbal learning style reveals that the p-value is more than 0.05 ; the null hypotheses accept at 5 per cent level of significance. It is concluded that there is no significant difference between gender and aural learning style ( $F=.100 ; p>0.05)$. 


\section{Brain's Hemisphere Lateralization and Learning Styles in Engineering Education}

As regards the above table physical learning style reveals that the p-value is more than 0.05; the null hypotheses accept at 5 per cent level of significance. It is concluded that there is no significant difference between gender and aural learning style $(F=1.823 ; p>0.05)$.

It is clear that the above table logical learning style reveals that the p-value is more than 0.05; the null hypotheses accept at 5 per cent level of significance. It is concluded that there is no significant difference between gender and aural learning style $(F=.125 ; \mathrm{p}>0.05)$.

It is focus that the above table social learning style reveals that the p-value is more than 0.05 ; the null hypotheses accept at 5 per cent level of significance. It is concluded that there is no significant difference between gender and aural learning style $(\mathrm{F}=1.074 ; \mathrm{p}>0.05)$.

It is shows that the above table solitary learning style reveal that the p-value is more than 0.05; the null hypotheses accept at 5 per cent level of significance. It is concluded that there is no significant difference between gender and aural learning style $(\mathrm{F}=2.226 ; \mathrm{p}>0.05)$.

\section{DISCUSSION AND CONCLUSION}

In the research it is seen that determine brain dominance and learning style of engineering college students and reveal the relations between them. The majority 338 respondents are male category (67.6\%) are using their right brain dominance. The majority of students are (68.4\%) EEE students. The majority of EEE department students were using left brain dominance at 31 per cent. According to this results obtained from there is a significant difference between gender and brain dominance and on other hand there is a significant difference between gender and department, in these mean while there is no significant difference between department and brain dominance. The One way finds the results that there is no significant difference between gender and learning styles.

\section{Acknowledgments}

The author appreciates all those who participated in the study and helped to facilitate the research process.

\section{Conflict of Interests}

The author declared no conflict of interests.

\section{REFERENCES}

Broca, P, (1861) “Remarques sur le siége de la faculté du language articulé, suivies d'une observation d'aphémie (perte de la parole)”. Bulletin de la Society Anatomique, 6, pp. 330-357.

C R Kothari and Gaurav Garg, (2014) “Research Methodology: Methods and Techniques”, New Age International (P) Limited, Publishers, New Delhi. ISBN: 978-81-224-3623-5. 
Dr. S.P. Gupta, (2014) “Statistical Methods”, Sultan Chand \& Sons, New Delhi. ISBN: 978-93161-028-1.

Herrmann, (2003) "The Herrmann Brain Dominance Instrument (HBDI)", Herrmann International Journal. (Online).

Honey, P. \& Mumford, A, (2000) “The learning styles helper's guide”, Maidenhead: Peter Honey Publications Ltd.

James B. Cunningham and James O. Aldrich, (2012) "Using SPSS: An Interactive Hands - on Approach”, Sage Publications’ India Pvt. Ltd., New Delhi. ISBN: 978-81-321-1016-3.

Kemal Özgena, Berna Tataroglua, Hüseyin Alkana, (2011) "An examination of brain dominance and learning styles of pre-service mathematics teachers”, Procedia Social and Behavioral Sciences 15 (2011) pp. 743-750

McCarthy, B., Germain, C.S., \& Lippitt, L, (2006) "The 4MAT research guide, reviews of Literature on individual differences and hemispheric specialization and their influence on Learning”, Illinois: About Learning Incorporated.

Riad S. Aisami, (2015) "Learning styles and visual literacy for learning and performance", Procedia - Social and Behavioral Sciences 176, pp 538 - 545.

Solso, R.L., Maclin, M.K., \& Maclin, O.H. (2007) “Bilissel psikoloji” (Çev. A. Ayçiçegi-Dinn). Istanbul: Kitabevi.

Robert H. Carver and Jane Gradwohl Nash, (2011) "Data Analysis with SPSS- Version 16", Cengage Learning India Private Limited, New Delhi. ISBN: 13: 978-81-315-1205-0.

How to cite this article: Gomathi A, Krishna K (2017), Brain's Hemisphere Lateralization and Learning Styles in Engineering Education, International Journal of Indian Psychology, Volume 4, Issue 2, No. 96, ISSN:2348-5396 (e), ISSN:2349-3429 (p), DIP:18.01.182/20170402, ISBN:978-1-365-84232-0 